\title{
IKON HABIBIE-AINUN, STRATEGI INOVATIF DALAM MENGEMBANGKAN PARIWISATA DI KOTA PAREPARE, SULAWESI SELATAN
}

\author{
Ilham Junaid dan Hamsu Hanafi \\ Politeknik Pariwisata (Poltekpar) Makassar \\ Email : illank77@yahoo.co.id dan hamsu_ham@yahoo.com
}

\begin{abstract}
Empirical data on how the local governments implement tourism innovation is very limited. Thus, it is necessary to explore how the regional board of tourism develops tourism potential through innovative approach. The aims of this research are to explore the festival of Habibie-Ainun as well as to recommend ways in optimizing the festival for community welfare. This research is a qualitative study by interviewing (in-depth interview) four staff at the regional board of tourism as well as doing participant observation at Parepare city. The research reveals that HabibieAinun is choosen as an icon of tourism because of the enchantment of Habibie, the former president of Indonesia who was born in Parepare city. Habibie-Ainun festival, becak of tourism and the statue of Habibie-Ainun are considered as innovative strategies in attracting tourists. This research suggests that strategy of HabibieAinun should be supported with various and continuous activities that may involve tourists particularly in the area of the statue. The local government should also inform the community on how the strategy can help community improve their income through tourism. Innovative strategies may come from the community, and thus, it is important to strengthen synergy between the local government and the community.
\end{abstract}

Keywords :Habibie-Ainun, innovative strategy, tourism development, Parepare city

\section{Pendahuluan}

Dalam beberapa dekade terakhir, pariwisata menjadi industri penting yang diyakini mampu memberikan kontribusi positif dalam mencapai kesejahteraan masyarakat suatu destinasi. Jumlah wisatawan yang melakukan kunjungan di seluruh dunia yang semakin mengalami peningkatan adalah salah satu indikator pentingnya industri pariwisata. Atas dasar inilah, berbagai upaya dilakukan untuk menarik wisatawan agar menentukan pilihan kunjungannya ke destinasi yang dipromosikan. 
Di Indonesia, hampir seluruh destinasi wisata baik kabupaten/kota maupun provinsi berusaha menarik wisatawan domestik dan internasional untuk datang berkunjung ke daerah mereka. Dengan usaha promosi ini, maka ada harapan yang besar bahwa pariwisata menjadi berkembang dan memberikan dampak positif terhadap masyarakatnya. Jika seluruh destinasi bekerja memaksimalkan promosi mereka untuk menarik wisatawan, maka persaingan memperebutkan hati wisatawan menjadi tak terhindarkan. Hal ini berarti bahwa pihak-pihak yang memiliki otoritas mempromosikan daya tarik wisata harus menemukan dan mengimplementasikan manajemen strategis yang mampu memenangkan persaingan menarik wisatawan berkunjung ke destinasi wisata.

Salah satu upaya dalam mengelola pariwisata daerah adalah pentingnya menerapkan inovasi-inovasi pariwisata (Pereira 2016). Inovasi dapat berarti suatu upaya atau strategi yang bersifat kebaruan dalam mengelola ataupun mempromosikan daya tarik wisata dan destinasi wisata. Namun demikian, meskipun inovasi ini diyakini sangat penting dalam pengembangan pariwisata, strategi inovatif masih sangat sedikit diterapkan oleh stakeholder pariwisata di daerah (Weiermair 2006). Selain itu, terdapat kecenderungan bahwa studi inovasi dalam perspektif pemerintah sebagai pelaksana khususnya dalam konteks Indonesia masih sangat terbatas. Hal ini terlihat dari terbatasnya publikasi yang berkaitan dengan inovasi pariwisata.

Langkah-langkah inovatif yang dilakukan pemerintah daerah di Indonesia perlu mendapat perhatian agar menjadi contoh bagi daerah lain dalam mengelola pariwisata daerah. Sebaliknya, tidak sedikit daerah yang kurang memberikan perhatian terhadap pentingnya menerapkan strategi kebaruan dalam mengelola dan mempromosikan daya tarik wisata. Jika upaya inovatif ini kurang menjadi perhatian, maka ada kemungkinan bahwa pariwisata hanya dikelola apa adanya tanpa ada upaya untuk memaksimalkan pariwisata sebagai alternatif membantu perekonomian masyarakat.

Umumnya, aktivitas yang berhubungan dengan pariwisata daerah dikelola oleh dinas pariwisata kabupaten dan kota. Karena itu, staf yang berada di Dinas pariwisata kabupaten dan kota diharapkan memberikan andil yang besar dalam melakukan upaya kreatif pengembangan pariwisata. Mei, Arcodia dan Ruhanen (2013) mengemukakan bahwa kajian tentang peran pemerintah daerah dalam mengembangkan pariwisata melalui pendekatan inovasi pariwisata masih terbatas. Karena itu, dinas pariwisata kabupaten dan kota diharapkan bekerja semaksimal mungkin untuk menerapkan langkah atau upaya inovatif pengembangan pariwisata daerah. Dalam hal ini, Kota Parepare sebagai salah satu kota di Sulawesi Selatan diharapkan mampu menerapkan strategi kebaruan yang berhubungan dengan pariwisata mengingat kota ini merupakan persinggahan utama wisatawan sebelum tiba di Toraja, salah satu andalan destinasi wisata Sulawesi Selatan dan Indonesia 
secara umum. Potensi pariwisata (wisata alam dan budaya) dan lokasi strategis Kota Parepare menjadi alasan utama pentingnya mengeksplorasi lebih jauh inovasi pariwisata baik yang telah dilakukan oleh pemerintah daerah maupun yang sedang direncanakan oleh Dinas pariwisata.

Tujuan karya tulis ini adalah untuk menguraikan langkah-langkah inovatif yang dilakukan pemerintah daerah Kota Parepare, dalam hal ini Dinas Olahraga, Pemuda dan Pariwisata (OPP) dalam mengembangkan pariwisata daerah. Festival cinta sejati Habibie-Ainun dan hal- hal yang berhubungan dengan ikon Habibie-Ainun menjadi perhatian penulis dalam menguraikan inovasi pariwisata di Kota Parepare. Selanjutnya, tulisan ini mengusulkan langkah-langkah atau upaya dalam mengoptimalkan inovasi pariwisata daerah agar dapat memberikan manfaat yang lebih besar bagi kesejahteraan ekonomis masyarakat dan pengembangan pariwisata secara umum.

\section{Teori dan Metodologi Penelitian}

\subsection{Defenisi Inovasi Pariwisata}

Istilah inovasi sering dihubungkan dengan hal-hal yang berkaitan dengan teknologi serta penemuan-penemuan yang bersifat kebaruan. Pariwisata juga tidak terlepas dari bagaimana menyusun strategi pengembangan pariwisata yang bersifat kebaruan. Inovasi dapat berarti proses perubahan atau hasil dari proses perubahan tersebut baik yang bersifat produk, pelayanan maupun inovasi organisasi atau institusi (Mattsson, Sundbo, dan Fussing-Jensen 2005). Hasil dari suatu proses pengembangan merupakan bagian dari inovasi itu sendiri sedangkan segala aktifitas yang berkaitan dengan upaya menghasilkan inovasi diartikan sebagai inovasi kegiatan. Dari uraian ini dapat dipahami bahwa inovasi ditunjukkan dalam dua kategori yakni inovasi hasil (suatu strategi atau perubahan yang diterapkan) dan inovasi proses (pelaksanaan suatu strategi inovatif).

Penelitian tentang inovasi itu sendiri telah dimulai sekitar tahun 1960an dengan kajian dari berbagai perspektif (Hjalager 2009). Dalam sektor pariwisata, penelitian yang berhubungan dengan inovasi lebih tertuju pada sektor pelayanan khususnya bidang hospitaliti. Sektor pelayanan yang dimaksud juga berkaitan dengan inovasi yang dilakukan suatu perusahaan atau industri-industri. Dalam perkembangannya, penelitian yang berhubungan dengan inovasi produk yang dihasilkan suatu industri atau perusahaan menjadi kajian banyak peneliti. Menurut Hjalager (2009), produk-produk pariwisata juga telah mengalami perkembangan. Karena itu, penelitian inovasi produk pariwisata juga menjadi penting untuk memahami bagaimana individu atau organisasi mengelola daya tarik wisata melalui pendekatan langkah-langkah inovatif. 
Inovasi juga banyak diidentikkan dengan sistem inovasi. Edquist (2001:14) dalam Hjalager (2009:268) mengemukakan bahwa sistem inovasi adalah "all important economic social, political, organizational, and other factors that influence the development, diffusion, and use of innovation". Sistem inovasi diartikan sebagai segala sesuatu atau faktor-faktor yang memengaruhi pengembangan, difusi atau penyebaran. Faktor-faktor tersebut dapat berupa faktor ekonomi, sosial, politik, organisasi dan berbagai faktor lainnya. Dari defenisi ini dapat dipahami bahwa sistem inovasi merupakan segala aspek yang berkaitan dengan usaha manusia menciptakan atau membuat aktifitas yang bertujuan untuk lebih mengembangkan hasil suatu pengembangan atau pengelolaan.

Inovasi tidak dapat dipisahkan dari pemerintah atau mereka yang berada dalam naungan organisasi pemerintah. Menurut Lundval (2005), meskipun banyak inovasi dilahirkan dari kalangan masyarakat lokal atau dari kelompok-kelompok masyarakat, peran pemerintah tetap menjadi penentu terciptanya dan terimplementasinya aktifitas atau langkah-langkah inovatif. Hal ini berarti bahwa pemerintah diharapkan tidak hanya merencanakan program pengembangan pariwisata yang bersifat jangka pendek, menengah dan panjang, tetapi memikirkan upaya kreatif dan inovatif yang mampu mencapai target pengembangan pariwisata.

Upaya inovatif yang dilakukan tidak dapat berjalan tanpa dukungan dan partisipasi dari berbagai kalangan atau kelompok masyarakat. Jika seseorang mengusulkan suatu langkah-langkah yang harus dilakukan (yang bersifat inovatif) dalam pengelolaan daya tarik wisata misalnya, maka saat itu pula seseorang tersebut membutuhkan pihak lain agar inovasi yang diusulkan dapat berjalan sesuai dengan rencana program kerja. Inovasi merupakan proses yang bersifat komulatif yang lahir dari proses pembelajaran dan pencarian suatu strategi (Hjalager 2009; Volo 2005; Williams dan Shaw 2011). Dalam hal ini, ada usaha bersama dalam menghasilkan pengetahuan yang bersifat kebaruan dan penyebaran (difusi) pengetahuan tersebut.

Pariwisata merupakan kegiatan yang kompleks. Kompleksitas tersebut dilihat dari bagaimana mengelola sumber-sumber (alam dan budaya) untuk kepentingan pariwisata, bagaimana interaksi wisatawan dengan sumbersumber pariwisata serta bagaimana interaksi wisatawan dengan masyarakat suatu destinasi (Mason 2003). Aspek-aspek tersebut membutuhkan suatu upaya, strategi ataupun pendekatan dalam mengelola dan mengembangkan pariwisata.

Seiring dengan usaha yang dilakukan oleh pemerintah di setiap negara di dunia dalam mempromosikan aset pariwisata, ada harapan yang besar bahwa inovasi sangat dibutuhkan dalam memaksimalkan promosi tersebut. Pentingnya inovasi ini didasarkan pada realita bahwa setiap destinasi harus mampu bersaing dalam memenangkan kompetisi menarik wisatawan. Inovasi 
diyakini sebagai aspek penting dalam pengelolaan daya tarik wisata di suatu destinasi. Namun demikian, di balik pentingnya inovasi tersebut, penelitian tentang inovasi masih sangat terbatas (Hjalager 2010; Tejada dan Moreno 2013) khususnya yang berkaitan dengan bagaimana pemerintah daerah melakukan inovasi serta kaitan inovasi dengan keberhasilan pengembangan pariwisata suatu daerah. Karena itu, inovasi menjadi pilihan alternatif dalam mengelola aset pariwisata daerah. Di Indonesia, kegiatan pariwisata daerah umumnya dikelola oleh pemerintah melalui peran dinas pariwisata kabupaten dan kota. Peran perencanaan dan pengelolaan ini adalah indikasi bahwa pemerintah daerah perlu memikirkan dan menerapkan inovasi pariwisata dalam mengelola aset daerah.

Untuk memahami inovasi pariwisata, Tejada dan Moreno (2013) mengemukakan empat jenis atau tipe inovasi yakni inovasi produk, proses, pemasaran dan organisasional. Inovasi produk pariwisata pariwisata dapat diartikan sebagai langkah-langkah kebaruan dalam mengelola dan mengembangkan produk pariwisata yang menjadi target pengembangan. Dalam hal ini, produk pariwisata lebih difokuskan pada daya tarik wisata yang menjadi tujuan kunjungan wisatawan. Inovasi produk yang bersifat nyata (tangible) dapat menjadi acuan langkah-langkah inovatif yang dilaksanakan oleh suatu pengelola daya tarik wisata.

\subsection{Peran Stakeholder dalam Inovasi Pariwisata}

Keterlibatan stakeholder menjadi kata kunci jika suatu daerah akan dikembangkan sebagai destinasi wisata. Stakeholder umumnya diterjemahkan sebagai pemangku kepentingan yang berarti kelompok ataupun individu yang memiliki kepentingan dalam pengembangan pariwisata. Freeman (1984:46) dalam Byrd (2007:1) mengemukakan bahwa stakeholder dapat diartikan sebagai "any group or individual who can affect or is affected by tourism”. Stakeholder juga dapat diartikan sebagai mereka yang memberikan pengaruh atau dipengaruhi dengan adanya kegiatan pariwisata. Pemerintah, industri pariwisata, masyarakat khususnya mereka yang tinggal di sekitar daya tarik wisata merupakan contoh-contoh stakeholder.

Kebijakan pengembangan destinasi wisata yang efektif membutuhkan keterlibatan sebanyak-banyaknya stakeholder khususnya dalam merencanakan dan mengimplementasikan kebijakan (Ioannides 2008; Mitchell 2008). Hal ini sangat penting untuk pencapaian tujuan pariwisata yang berkelanjutan sebagaimana banyak diharapkan oleh para pemangku kepentingan pariwisata. Pentingnya keterlibatan stakeholder dalam inovasi pariwisata terbukti telah mampu mengembangkan pariwisata ataupun daya tarik yang sedang dikembangkan di sebuah negara. Di Australia misalnya, kesuksesan pengelolaan daya tarik wisata The Tjapukai Aboriginal 
Cultural Park di daerah Queenslad, telah mampu mengintegrasikan antara keterlibatan masyarakat suku Aborigin dan kemampuan untuk berinovasi dan melakukan komunikasi cross-cultural yang berdampak pada pengembangan daya tarik tersebut (Mercer 2005). Ini berarti bahwa kesiapan keterlibatan stakeholder akan membantu untuk memudahkan adanya upaya kreatif melalui inovasi pariwisata.

Idealnya, pariwisata tidak hanya dikembangkan, dikelola ataupun dioperasikanolehpemerintah semata. Keterlibatanstakeholderyangberagam akan memberikan pengaruh terhadap pengelolaan daya tarik wisata yang ada. Menurut Bramwell (2005), dominasi pemerintah dalam pengelolaan pariwisata cenderung menyebabkan pengelolaan dengan birokrasi yang sulit. Karena itu, pemerintah sebagai stakeholder utama sangat diharapkan dalam memberikan pelatihan dan pendidikan tentang pariwisata kepada masyarakat, sektor industri dan stakeholder lainnya (Butler 1991; Bramwell 2005). Pendidikan pariwisata dan hal-hal yang berkaitan dengan upayaupaya inovatif perlu difasilitasi oleh pemerintah melalui perannya sebagai pemberi pendidikan dan pelatihan untuk masyarakat.

Dari penjelasan di atas, nampak bahwa inovasi pariwisata tidak hanya diciptakan oleh pemerintah sebagai perencana dan pengelola pariwisata. Manfaat yang dirasakan dengan adanya inovasi pariwisata adalah bahwa usaha kreatif melalui langkah inovasi memberikan keuntungan yang besar dalam pertumbuhan ekonomi (Shaw 2004). Butler (2004) mengemukakan bahwa dengan adanya inovasi, peluang untuk melakukan perubahan yang bersifat kemajuan akan semakin terbuka. Menurutnya, saat ini, pengelola daya tarik wisata kurang memerhatikan aspek kreatif dan inovasi dalam mengembangkan pariwisata (Butler 2004). Hal ini menyebabkan produk pariwisata yang ditawarkan ke wisatawan menjadi kurang menarik dan cenderung disajikan apa adanya. Dengan kata lain, produk pariwisata terkesan apa adanya tanpa ada usaha kreatif dan inovatif dalam menarik wisatawan untuk berkunjung ke daya tarik tersebut.

\subsection{Metodologi Penelitian}

Untuk mencapai tujuan penelitian, peneliti menerapkan metode penelitian kualitatif. Menurut Flick (2007), penelitian kualitatif bertujuan untuk memahami, menguraikan dan menjelaskan fenomena sosial dalam perspektif individu atau mereka yang terlibat dalam penelitian. Penelitian kualitatif dilakukan dengan menganalisis pengalaman individu-individu atau kelompok, interaksi dan komunikasi yang terjadi serta dokumen-dokumen yang berkaitan dengan topik penelitian (Flick 2007; Flick, Kardorff, dan Steinke 2004; Goodson dan Phillimore 2004).

Penelitian dilakukan di Kota Parepare pada bulan Mei 2016 dengan melakukan kunjungan langsung ke kantor Dinas Olahraga, Pemuda 
dan Pariwisata (OPP). Pengumpulan data dilakukan dengan wawancara mendalam (in-depth interview) kepada staf di Dinas OPP. Empat orang staf di Dinas OPP Kota Parepare memberikan informasi penting mengenai upayaupaya inovatif yang telah dilakukan melalui wawancara mendalam yang berlangsung antara 30 hingga 45 menit. Pengumpulan data penelitian juga dilakukan melalui observasi sebagai wisatawan (participant observation) dengan melihat secara langsung Kota Parepare. Observasi juga dilakukan dengan kunjungan ke daya tarik wisata yang ada di kota tersebut. Data yang diperoleh melalui dokumen pemerintah dan publikasi ilmiah menjadi data penting dalam menguraikan inovasi pariwisata yang dilakukan oleh pemerintah daerah.

Data kualitatif tersebut dianalisis dengan prinsip analisis data kualitatif. Menurut Liamputtong (2009), analisis data kualitatif dimulai ketika peneliti telah mulai mengumpulkan data baik melalui wawancara, observasi dan review dokumen. Secara khusus, prinsip analisis tematik (thematic analysis) memandu peneliti dalam menemukan kategori-kategori yang ada dalam data kualitatif. Liamputtong berpendapat bahwa analisis tematik adalah metode mengidentifikasi, menganalisis dan menuliskan tema-tema (pola-pola) yang ada dalam data tersebut.

\section{Sekilas tentang Pemilihan Ikon Habibie-Ainun}

Di Provinsi Sulawesi Selatan, terdapat tiga wilayah yang telah mandiri sebagai kota administratif, tidak menggunakan istilah kabupaten yakni Kota Makassar, Kota Parepare dan Kota Palopo. Kota Parepare secara khusus merupakan daerah yang strategis karena wisatawan akan melewati daerah ini ketika mereka akan melakukan perjalanan menuju Toraja, ikon pariwisata Sulawesi Selatan dan Indonesia secara umum. Kota Parepare dijadikan sebagai daerah atau tempat transit setelah wisatawan melakukan perjalanan kurang lebih tiga hingga empat jam dari Kota Makassar, ibukota Provinsi Sulawesi Selatan.

Kota Parepare identik dengan mantan presiden Republik, Indonesia, Prof. Dr. Ing. B.J. Habibie karena di kota ini beliau dilahirkan. Ikatan moral inilah yang menjadikan rakyat kota Parepare mencintai figur seorang B.J. Habibie dan bangga dengan putra daerah. Sebagai bukti kebanggaan tersebut, ketika memasuki kota Parepare, pengunjung akan disambut dengan kalimat "Di Kota Ini Lahir Pemimpin Bangsa, B.J. Habibie”, sebuah slogan yang menunjukkan kebahagiaan memiliki seorang figur yang bisa menjadi panutan bagi generasi muda khususnya pemuda-pemudi Kota Parepare. Karena faktor inilah, mantan presiden B.J. Habibie sering meluangkan waktu untuk mengunjungi Kota Parepare dan disambut meriah oleh masyarakat di daerah tersebut.

Seiring dengan upaya pemerintah daerah Kota Parepare untuk menjadikan daerah ini sebagai destinasi utama di Sulawesi Selatan, maka upaya 
untuk melakukan terobosan terus diupayakan untuk mewujudkan tujuan tersebut. Konsep pengembangan pariwisata di Kota Parepare adalah optimalisasi pariwisata Kota Parepare sebagai destinasi wisata perkotaan (urban tourism) dan destinasi wisata belanja (shopping tourism). Konsep ini sejalan dengan potensi kewilayahan yang dimiliki serta daya tarik wisata yang banyak dikunjungi oleh wisatawan. Urban tourism menjadi pilihan kota ini mengingat nuansa kota kecil yang bersih dan menyodorkan keindahan alam namun dekat dengan nuansa modern yang bersifat kedaerahan (tradisional). Shopping tourism menjadi pilihan mengingat kota ini menjadi pilihan para pembelanja yang datang dari berbagai daerah di Sulawesi Selatan maupun mereka yang transit sementara baik melalui perjalanan darat maupun melalui perjalanan laut oleh wisatawan asing (kapal pesiar) yang singgah melalui pelabuhan di Kota Parepare. Pusat pakaian bekas (pasar senggol), barang-barang bekas berkualitas (Carlos) serta makanan tradisional (kuliner) bugis menjadi ciri khas mengapa kota ini memilih konsep shopping tourism sebagai strategi pengembangan pariwisata daerah.

Potensi daya tarik wisata alam dan budaya yang dimiliki menjadikan kota ini sebagai primadona bagi wisatawan yang melakukan perjalanan dan melalui kota ini. Pantai, usaha-usaha kreatif bidang pariwisata serta kegiatan atau event tahunan menjadi daya tarik yang dijual ke wisatawan. Festival cinta sejati Habibie-Ainun menjadi tren dan strategi baru yang dijalankan oleh pemerintah daerah dalam mendongkrak pariwisata demi peningkatan perekonomian masyarakat. Di tahun 2016, festival cinta sejati Habibie-Ainun telah memasuki pelaksanaan yang kedua kali. Setelah sukses melaksanakan event tersebut pada tahun sebelumnya, pemerintah daerah kembali melaksanakan event yang sama di bulan Mei tahun 2016.

Munculnya ide ikon Habibie-Ainun didasarkan pada pertimbangan bahwa Parepare harus memiliki satu ikon yang mampu memberikan kesan positif kepada wisatawan ketika mereka mengunjungi Kota Parepare. Jika Toraja memiliki ikon Tongkonan, rumah tradisional dengan keunikan bentuk atap yang melengkung, Kabupaten Bulukumba memiliki perahu pinisi dengan ciri khas tradisionalnya, maka Parepare juga harus memiliki ikon yang mudah diingat oleh wisatawan. Pada tahun 2014, ikon HabibieAinin lahir dari hasil kesepakatan bersama masyarakat Parepare dalam sebuah forum yang disebut "forum kreatifitas pariwisata Parepare". Secara khusus, istilah Habibie-Ainun merupakan ide dari bupati Kota Parepare yang melihat potensi kedaerahan dan kekhasan pengunjung atau wisatawan yang umumnya adalah dari Jerman. Kedatangan wisatawan Jerman tersebut semakin meningkat khususnya ketika kunjungan melalui pelabuhan Parepare (kapal pesiar) yang membawa wisatawan tersebut. Sejak tahun 2014 hingga saat ini, ikon Habibie-Ainun dijadikan tagline utama dalam mempromosikan Kota Parepare baik nasional maupun internasional. 


\section{Langkah-Langkah Inovatif dalam Mendukung Pariwisata melalui Ikon Habibie-Ainun}

Ikon Habibie-Ainun tidak hanya dijadikan sebagai slogan ataupun branding dalam mempromosikan daya tarik wisata yang ada di Kota Parepare. Pemerintah daerah (melalui Dinas Olahraga, Pemuda dan Pariwisata) menyadari bahwa slogan tersebut harus didukung dengan upayaupaya kreatif yang diharapkan mampu mencerminkan dan mendukung ikon Habibie-Ainun. Festival Habibie-Ainun yang telah dilaksanakan selama dua kali berturut-turut mulai tahun 2015 hingga tahun 2016 harus ditunjang dengan berbagai aktifitas yang melibatkan masyarakat setempat dan berbagai stakeholder lainnya. Upaya kreatif tersebut ternyata menghasilkan langkah-langkah inovatif yang dapat menjadi motivasi bagi stakeholder yang ada bahwa Kota Parepare yang kecil dan strategis tersebut mampu menarik wisatawan domestik dan internasional.

Pelaksanaan festival cinta sejati Habibie-Ainun pada tahun 2016 mampu mengajak masyarakat Kota Parepare dari berbagai kalangan untuk terlibat secara aktif mensukseskan event tersebut. Pernikahan massal yang diperuntukkan baik bagi masyarakat yang sudah lama menikah tapi belum memiliki buku nikah maupun bagi masyarakat yang merupakan pasangan baru terbukti mampu menarik perhatian masyarakat Kota Parepare. Uniknya, pasangan yang mengikuti pernikahan massal ini dibatasi hingga 54 pasang yang disesuaikan dengan usia pernikahan Habibie-Ainun. Seorang informan mengemukakan:

pada tanggal 12 Mei 2016 akan diadakan Festival Cinta Sejati Habibie dan Ainun. Yang menariknya dari festival ini adalah pada saat festival, juga akan dilangsungkan acara menikah massal baik bagi pasangan baru dan juga bagi pasangan yang sudah lama menikah tetapi belum memiliki buku nikah. Pasangan yang akan menikah massal berjumlah 54 pasang, sesuai dengan dengan umur pernikahan Habibie dan Ainun. Jumlah pasangan yang telah mendaftar untuk menikah massal saat ini sudah mencapai 51 pasangan (Wawancara, 28 April 2016).

Dilihat dari perspektif pariwisata, maka sesungguhnya pernikahan massal ini dapat dikategorikan sebagai strategi inovatif dengan rangkaian festival cinta sejati Habibie-Ainun sebagai event utama. Peran pemerintah sebagai penggerak inovasi pariwisata terbukti mampu menjadi motivator dalam mengajak masyarakat memahami makna pariwisata bagi pengembangan daerah. Macbeth, Carson, dan Northcote (2004) berpendapat bahwa pemerintah daerah bertanggung jawab menciptakan dan mengupayakan langkah inovatif dalam mencapai pengembangan daerah dengan prinsip keberlanjutan. Mengingat hampir setiap daerah (khususunya pemerintah daerah) di Indonesia terkendala dengan kemampuan pemerintah dalam 

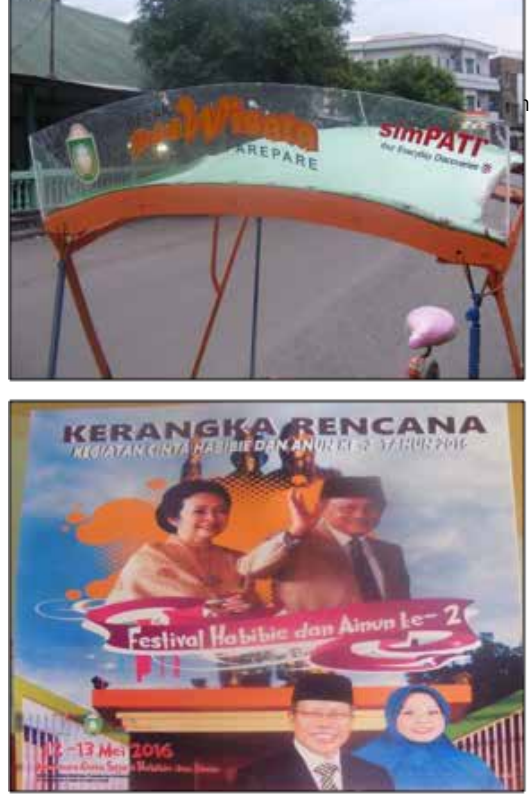

Foto 2. Becak wisata dan upaya kreatif di Kota Parepare

mengembangkan pariwisata daerah. Dilihat dari waktu yang dibutuhkan untuk mengembangkan pariwisata daerah, eksistensi patung tersebut merupakan langkah awal sekaligus merupakan proses yang berkelanjutan dalam mendongkrak jumlah wisatawan yang datang ke Kota Parepare. Dukungan aktifitas pariwisata berupa event atau festival menjadi penarik bagi para wisatawan yang merupakan pasar utama pengembangan pariwisata. Pelaksanaan event atau festival di Kota Parepare tersebut selanjutnya menjadi strategi inovatif dalam menjangkau pasar wisatawan dari berbagai kalangan.

Pemerintah Kota Parepare berencana akan membangun gedung yang bertemakan Habibie-Ainun dengan konsep “Balai Ainun”. Bangunan tersebut juga merupakan strategi inovatif dimana aktifitas yang akan dilaksanakan lebih diarahkan pada upaya memberdayakan perempuan khususnya warga Kota Parepare. Dalam gedung ini pula akan dibangun museum HabibieAinun dimana koleksinya merupakan benda-benda yang berkaitan dengan Bapak Habibie dan Ibu Ainun. Gedung ini pula akan dijadikan sebagai pusat hasil kerajinan tangan (handicraft) yang merupakan karya-karya masyarakat Kota Parepare khususunya warga perempuan.

Dari segi pelayanan ke wisatawan, pemerintah Kota Parepare melalui Dinas Olahraga, Pemuda dan Pariwisata melakukan langkah inovatif dengan membuat membuat becak wisata yang diperuntukkan untuk wisatawan yang datang ke Kota Parepare. Becak wisata ini diperuntukkan bagi wisatawan asing (kapal pesiar) yang tiba di pelabuhan Kota Parepare dan menyempatkan diri untuk mengenal (eksplorasi) kota.

Becak wisata ini dilengkapi dengan sistem atau software yang dapat dimanfaatkan oleh wisatawan dalam mengenal Kota Parepare. Dengan 
sistem tombol yang disediakan di setiap becak wisata tersebut, pengunjung atau wisatawan dapat mendengarkan informasi mengenai daya tarik wisata Parepare sambil melihat kota di atas becak. Upaya kreatif ini menjadi salah satu strategi pemerintah daerah dalam memberikan pelayanan ke wisatawan. Staf di Dinas Olahraga, Pemuda dan Pariwisata mengungkapkan:

langkah inovasi yang dilakukan oleh dinas pariwisata adalah dengan merekam suara mengenai penjelasan daya tarik wisata, dimana tukang becak tersebut hanya tinggal menekan tombol/angka yang telah disesuaikan dengan DTW yang dikunjungi dan becak tersebut masih terbatas, yaitu terdapat hanya 5 Unit. Misalnya, mengenai monumen Habibie Ainun terekam pada nomor 1 maka tombol yang ditekan adalah nomor 1 di mana suara yang terdengar akan menjelaskan mengenai monumen Habibie Ainun (Wawancara, 28 April 2016).

Dari upaya inovatif yang dilakukan oleh pemerintah daerah Kota Parepare, terdapat langkah-langkah dalam mengoptimalkan upaya kreatif tersebut agar tujuan dan target pengembangan pariwisata dapat tercapai. Hal ini juga berkaitan dengan pelajaran yang dapat diambil dari upaya inovatif yang dilakukan oleh pemerintah Kota Parepare. Berikut ini merupakan uraian optimalisasi upaya inovatif pengembangan pariwisata daerah di Kota Parepare:

1. Pariwisata menghendaki partisipasi aktif dari masyarakat serta kemanfaatan ekonomis bagi masyarakat. Untuk mencapai tujuan ini, pemerintah daerah perlu mengidentifikasi upaya-upaya inovatif yang telah dan sedang dilakukan oleh masyarakat setempat. Secara totalitas, banyak masyarakat yang belum memahami bagaimana memasarkan produk inovatif yang mereka hasilkan. Mereka juga lemah dalam memahami produk inovatif pariwisata yang dapat dijual ke wisatawan. Peran pemerintah daerah dalam mengidentifikasi usaha dan upaya kreatif tersebut akan menjadi jembatan bagi masyarakat untuk merasakan manfaat pariwisata secara menyeluruh.

2. Pemerintah daerah (kabupaten dan kota) di Sulawesi Selatan dan Indonesia secara umum dapat meniru pendekatan yang dilakukan oleh pemerintah Kota Parepare dalam mengembangkan pariwisata daerah. Namun demikian, upaya kreatif sangat dibutuhkan dengan melihat potensi kedaerahan yang dimiliki serta karakteristik wisatawan dan pengembangan pariwisata daerah yang dapat diterapkan.

3. Upaya inovatif yang telah dilakukan perlu didukung dengan aktifitas atau kegiatan yang mengajak wisatawan untuk terlibat secara fisik. Sebagai contoh, keberadaan patung Habibie-Ainun perlu didukung dengan aktifitas yang berkesinambungan, misalnya perlunya membuat suatu sistem dengan pemanfaatan teknologi dimana wisatawan dapat memperoleh gambaran tidak hanya melalui diorama, tetapi 
memanfaatkan inovasi teknologi. Jika hal ini dapat diterapkan, maka sistem keamanan perlu ditingkatkan mengingat penggunaan teknologi dapat berdampak pada sistem pengamanan peralatan yang digunakan.

4. Becak wisata yang telah dijalankan nampaknya masih perlu dievaluasi mengingat wawancara informal tim peneliti dengan masyarakat Kota Parepare khususnya pegawai hotel menunjukkan kurangnya pengetahuan dan informasi yang dimiliki masyarakat mengenai becak wisata tersebut. Para staf di hotel tempat kami menginap tidak mengetahui adanya becak wisata ini. Idealnya, perlu ada sinergi yang baik antara program yang dijalankan pemerintah dengan industri pariwisata di kota tersebut. Industri pariwisata khususnya hotel merupakan ujung tombak penyampai informasi ke wisatawan mengenai potensi pariwisata yang dimiliki oleh suatu daerah. Karena itu, upaya optimalisasi inovasi pariwisata seharusnya menggandeng industri pariwisata sebagai mitra mengembangkan pariwisata daerah.

5. Pada umumnya, dinas pariwisata daerah memiliki kendala dalam hal keterbatasan sumber daya manusiayang kompeten dibidang pariwisata. Pemerintah membutuhkan karyawan atau staf yang mampu berfikir inovatif dalam merencanakan dan menjalankan program kerja bidang kepariwisataan. Untuk mengatasi kendala ini dibutuhkan sinergi yang kuat antara institusi pendidikan atau perguruan tinggi khususnya bidang hospitaliti dan kepariwisataan dengan dinas pariwisata daerah dalam menjalankan program kerja yang inovatif. Selain tuntutan dinas pariwisata daerah dalam menerapkan langkah-langkah inovatif, sinergi dengan pendidikan tinggi akan sangat membantu pemerintah daerah dalam menggali potensi daerah sekaligus mendorong upaya inovasi pariwisata daerah.

\section{Simpulan}

Persaingandalammenarikwisatawanbaikdomestikmaupuninternasional menjadi salah satu alasan pentingnya suatu destinasi menerapkan langkahlangkah inovatif. Inovasi pariwisata yang diartikan sebagai langkah atau strategi kebaruan dalam mengemas dan mengembangkan produk pariwisata menjadi sangat penting jika suatu daerah mengalami penurunan dalam hal jumlah wisatawan. Suatu destinasi mengharapkan kunjungan wisatawan yang semakin meningkat yang pada akhirnya akan berdampak pada kesejahteraan ekonomis bagi masyarakatnya.

Pemerintah Kota Parepare telah melakukan inovasi pariwisata dengan melihat potensi kedaerahan yang dimiliki serta peluang dalam menarik wisatawan. Pemilihan ikon Habibie-Ainun menjadi langkah inovatif dalam mengajak wisatawan untuk mengenal dan mengeksplorasi Kota Parepare. 
Penyelenggaraan festival dengan mengangkat tema Habibie-Ainun nampaknya dapat menjadi contoh bagi daerah lain di Sulawesi Selatan dan Indonesia secara umum dalam mengembangkan pariwisata daerah melalui pendekatan inovasi pariwisata.

Upaya inovatif tersebut perlu dioptimalkan agar inovasi pariwisata memberikan manfaat yang besar bagi masyarakat. Sinergi yang baik antara dinas pariwisata daerah dan berbagai kelompok masyarakat (stakeholder) menjadi kunci utama dalam mendorong pariwisata sebagai penunjang kesejahteraan masyarakat. Kemitraan dengan sekolah atau perguruan tinggi hospitaliti dan pariwisata akan menunjang upaya inovasi pariwisata yang dilakukan oleh pemerintah daerah. Sinergi dengan institusi lain (khususnya industri pariwisata) juga perlu dibangun agar optimalisasi peran stakeholder dalam mengembangkan pariwisata dapat tercapai. Aktivitas yang dilakukan secara berkelanjutan juga perlu dibangun khususnya dalam menunjang eksistensi patung Habibie-Ainun sebagai ikon pariwisata daerah Kota Parepare.

\section{Ucapan Terima Kasih:}

Ucapan terima kasih disampaikan kepada Politeknik Pariwisata Makassar (Poltekpar Makassar) atas bantuan dana penelitian tahun anggaran 2016.

\section{Daftar Pustaka}

Bramwell, Bill. 2005. "Interventions and Policy Instruments for Sustainable Tourism”. Dalam William. F. Theobald, (ed). Global Tourism, Hal. 406-425. Amsterdam: Elsevier.

Butler, Richard. 2004. "The Tourism Area Life Cycle in the Twenty-First Century". Dalam Alan A. Lew dkk (eds). A companion to Tourism. Hal. 159-170. Malden: Blackwell.

Butler, Richard. W. 1991. "Tourism, Environment, and Sustainable Development". Environmental Conservation. Vol.18(3), pp. 201-209.

Byrd, Eryck. T. 2007. "Stakeholders in Sustainable Tourism Development and Their Roles: Applying Stakeholder Theory to Sustainable Tourism Development”. Tourism Revew, Vol. 62.

Flick, Uwe. 2007. Designing Qualitative Research. London: SAGE.

Flick, Uwe., Kardorff, Ernst von. dan Ines Steinke. 2004. "What is qualitative research? an introduction to the field”. Dalam Uwe Flick dkk (eds). A Companion to Qualitative Research. Hal. 3-12. London: SAGE.

Goodson, Lisa., dan Jenny Phillimore. 2004. "The Inquiry Paradigm in Qualitative Tourism Research”. Dalam Jenny Phillimore dan Lisa Goodson (eds). Qualitative research in tourism: Ontologies, epistemologies and methodologies. Hal. 3-29. New York: Routledge.

Hjalager, Anne-Mette. 2006. “The Marriage Between Welfare Services and Tourism-A 
Driving Force for Innovation?”. Journal of Quality Assurance in Hospitality \& Tourism, Vol. 6(3-4), pp. 7-29.

Hjalager, Anne-Mette. 2009. "Cultural Tourism Innovation Systems - The Roskilde Festival”. Scandinavian Journal of Hospitality and Tourism, Vol. 9(2-3), pp. 266-287.

Hjalager, Anne-Mette. 2010. “A Review of Innovation Research in Tourism”. Progress in Tourism Management, Vol. 31, pp. 1-12.

Ioannides, Dimitri. 2008. "Hypothesizing the shifting mosaic of attitudes through time: A dynamic framework for sustainable tourism development on a 'Mediterranean Isle'”. Dalam Stephen. F. McCool dan R. Neil Moisey (eds). Tourism, Recreation and Sustainability: Linking Culture and the Environment. Hal. 51-75. Wallingford: CABI.

Liamputtong, Pranee. 2009. "Qualitative Data Analysis: Conceptual and Practical Considerations”. Health Promotion Journal of Australia, Vol. 20(2), pp. 133139

Lundvall, B.-A. 2005. Innovation System Research and Policy. Where It Came From and Where It Should Go. Paper, Aalborg University.

Macbeth, Jim., Carson, Dean., dan, Jeremy Northcote. 2004. "Social Capital, Tourism And Regional Development: Spcc As a Basis for Innovation and Sustainability”. Current Issues in Tourism, Vol. 7(6), pp. 502-522.

Mason, Peter. 2003. Tourism Impacts, Planning and Management. Burlington, Butterworth-Heinemann.

Mattsson, Jan., Sundbo, Jon., dan Christjan Fussing-Jensen. 2005. "Innovation Systems in Tourism: The Roles of Attractors and Scene-Takers”. Industry and Innovation, Vol. 12(3), pp. 357-381.

Mercer, David. 2005. "The 'new pastoral industry?': Tourism in indigenous Australia”. Dalam William. F. Theobald (ed). Global Tourism. 140-162. Amsterdam: Elsevier.

Mitchell, Ross. E. 2008. "Community perspectives in sustainable tourism lessons from Peru”. Dalam Stepehen. F., McCool dan R. Neil. Moisey (eds). Tourism, Recreation and Sustainability: Linking Culture and the Environment. 51-75. Wallingford: CABI.

Pereira, Elisabeth. T., 2016. "Are the most competitive countries the most innovative ones?”. Dalam A-Ivaro Matias, dkk (eds). Impact Assessment in Tourism Economics. Hal. 97-112. Springer.

Sheehan, Lorn., Ritchie, J. R. Brent., dan Simon Hudson,. 2007. "The Destination Promotion Triad: Understanding Asymmetric Stakeholder Interdependencies Among the City, Hotels, and DMO”. Journal of Travel Research, Vol. 46, pp. 64-74.

Shaw, Gareth 2004. "Entrepreneurial cultures and small business enterprises in tourism”. Dalam Alan. A. Lew dkk (eds) A Companion to Tourism. Hal. 122-134. Malden: Blackwell. 
Tejada, Pilar., dan Pilar Moreno. 2013. "Patterns of Innovation in Tourism 'Small and Medium-Size Enterprises””. The Service Industries Journal, Vol. 33(7), pp. 749-758.

Volo, Serena. 2005. “A consumer-based measurement of tourism innovation”. Dalam Mike Peters dan Birgit Pikkemaat (eds). Innovation in hospitality and tourism. 73-87. New York: Haworth Hospitality Press.

Weiermair, Klaus. 2006. "Prospects for Innovation in Tourism". Journal Of Quality Assurance In Hospitality \& Tourism, Vol. 6(3-4), Pp. 59-72.

Williams, Allan. M., dan Gareth Shaw. 2011. "Internationalization and Innovation in Tourism”. Annals of Tourism Research, Vol. 38(1), pp. 27-51.

\section{Profil Penulis}

Ilham Junaid adalah dosen tetap pada Politeknik Pariwisata (Poltekpar) Makassar, Kementerian Pariwisata. Saat ini menjabat sebagai sekretaris program studi manajemen kepariwisataan Poltekpar Makassar. Ia menyelesaikan program Magister di Universitas Padjadjaran Bandung tahun 2009 dan menyelesaikan program doktor jurusan manajemen pariwisata tahun 2014 di Universitas Waikato, New Zealand. Disertasinya berjudul "Opportunities and challenges of cultural heritage tourism: Socio-economic politics of sustainable tourism in South Sulawesi Province, Indonesia".

Hamsu Hanafi adalah dosen tetap pada Politeknik Pariwisata (Poltekpar) Makassar, Kementerian Pariwisata. Ia menyelesaikan studi Magister bidang manajemen di Universitas Bungaya Makassar dan menyelesaikan S3 (program doktor) bidang manajemen sumber daya manusia di Universitas Muslim Indonesia, Makassar. Saat ini menjabat sebagai Ketua Jurusan Perjalanan Poltekpar Makassar. 